\title{
Clinical and preclinical translation of cell-based therapies using adipose tissue-derived cells
}

Jeffrey M Gimble ${ }^{1,2 *}$, Farshid Guilak ${ }^{3}$ and Bruce A Bunnel|1,5

\begin{abstract}
Adipose tissue is now recognized as an accessible, abundant, and reliable site for the isolation of adult stem cells suitable for tissue engineering and regenerative medicine applications. The past decade has witnessed an explosion of preclinical data relating to the isolation, characterization, cryopreservation, differentiation, and transplantation of freshly isolated stromal vascular fraction cells and adherent, cultureexpanded, adipose-derived stromal/stem cells in vitro and in animal models. This body of work has provided evidence supporting clinical translational applications of adipose-derived cells in safety and efficacy trials.

The present article reviews the case reports and phase I-III clinical evidence using autologous adiposederived cells that have been published, to date, in the fields of gastroenterology, neurology, orthopedics, reconstructive surgery, and related clinical disciplines. Future directions and challenges facing the field are discussed and evaluated.
\end{abstract}

\section{Introduction/overview}

Subcutaneous human adipose tissue is an abundant and accessible cell source for applications in tissue engineering and regenerative medicine. Investigators have explored methods to extract stromal/stem cells from the waste products of abdominoplasty, cosmetic surgery, and tumescent liposuction procedures. Routinely, the adipose tissue is digested with collagenase or related lytic enzymes to release a heterogeneous population of stromal vascular fraction (SVF) cells. The SVF cells can be used directly or can be cultured in plastic ware to select and expand an adherent population known as adipose-derived stromal/stem cells (ASCs).

\footnotetext{
*Correspondence: gimblejm@pbrc.edu

'Stem Cell Biology Laboratory, Pennington Biomedical Research Center, Louisiana State University System, 6400 Perkins Road, Baton Rouge, LA 70808, USA
}

Full list of author information is available at the end of the article
During the past decade, the body of literature relating to the isolation, characterization, differentiation, expansion, immunophenotype, immunomodulatory properties, and preclinical use of SVF cells and ASCs has increased dramatically (reviewed in [1-4]). These studies, conducted throughout the globe, have provided evidence on the safety and efficacy of SVF cells and ASCs in vivo using animal models. With these reproducible and independently generated data, regulatory authorities in multiple countries have permitted a limited number of clinical trials involving SVF cells and ASCs to move forward. The present concise review will focus on publications relating to these ongoing clinical trials, their outcomes, and the future clinical translation of adipose-derived, cell-based tissue engineering.

\section{Background}

Both ASCs and SVF cells have been used in preclinical models to treat acute and chronic diseases afflicting a range of tissues and organs as summarized in Table 1; this summary is by no means a complete survey of this extensive and emerging body of literature. The majority of preclinical studies using ASCs and SVF cells have been conducted in rodent models due to their size, cost, availability of antibody probes, and access to inbred, genetically modified, and transgenic strains. A small, but growing, number of experiments have sought to evaluate the impact of adipose-derived cells in large animal disease models; however, these studies in the dog, goat, horse, pig, rabbit, or sheep have been hampered by the lack of appropriate monoclonal antibody reagents for cell tracking and immunophenotypic characterization. Nevertheless, the data accumulated have been sufficient to allow clinical investigators to apply for regulatory approval of clinical trials in many countries around the world.

Before beginning clinical trials, it has been necessary to develop current good manufacturing practices for the production of clinical-grade human SVF cells and ASCs. The Food and Drug Administration [5], the European Medicines Agency [6], and other national regulatory authorities have developed guidelines for industry specifically for adult cell production that are generally considered biological products as opposed to devices or 
Table 1. Representative preclinical animal studies using adipose-derived stromal/stem cells and stromal vascular fraction cells

\begin{tabular}{|c|c|c|c|}
\hline Tissue type & Defect & Species & References \\
\hline \multirow[t]{3}{*}{ Adipose/soft tissue } & Fat pad generation & Murine, rat, ovine & {$[51-60]$} \\
\hline & Lipodystrophy & Murine & {$[48,61]$} \\
\hline & Burn/radiation trauma & Murine & {$[62-64]$} \\
\hline \multirow[t]{4}{*}{ Bone } & Critical sized defect & & \\
\hline & Craniofacial & Murine, rat & {$[65,66]$} \\
\hline & Long bone & Murine & {$[67]$} \\
\hline & Spinal fusion & Rat & {$[68,69]$} \\
\hline Cardiac & Myocardial infarction & Murine, rat & {$[42,43,70,71]$} \\
\hline \multirow[t]{3}{*}{ Central nervous system } & Vascular injury/stroke & Murine, rat & {$[44,46,72]$} \\
\hline & Spinal cord trauma & Rat & [47] \\
\hline & Multiple sclerosis & Murine & [33] \\
\hline Gastrointestinal tract & Crohn's disease/inflammatory bowel syndrome & Murine & [73] \\
\hline Hematopoiesis & Bone marrow transplantation & Murine & {$[74,75]$} \\
\hline Joint & Osteoarthritis & Canine, caprine, equine & {$[76-79]$} \\
\hline Liver & Acute toxicity/regeneration & Murine & {$[80-88]$} \\
\hline Pancreas & Type 1 diabetes mellitus & Murine, rat & {$[48,89,90]$} \\
\hline Renal & Acute ischemia & Rat & (JMG, unpublished) \\
\hline Skin & Wounds, burns & Murine, porcine & {$[62,64,91]$} \\
\hline Tendon & Tendonitis & Equine & [92] \\
\hline Urinary bladder & Incontinence & Rat & [93] \\
\hline Vascular & Hind limb ischemia & Murine, rat & {$[36,41,45]$} \\
\hline
\end{tabular}

drugs. These guidance documents continue to be revised and updated as new evidence and products are evaluated. In general, cell products are divided into those that are minimally manipulated (such as autologous unfractionated circulating blood cells) or those that more than minimally manipulated (culture-expanded allogeneic bone marrow mesenchymal stem cells). Therapies involving minimally manipulated cells can advance more rapidly to the clinic. Nevertheless, both products face similar oversight requirements with respect to testing for contaminants.

All products must be evaluated for aerobic and anaerobic bacteria, endotoxin, and mycoplasma. If the cells are used for allogeneic purposes, either tissue donors or the cells themselves must be screened for a panel of viral agents, including cytomegalovirus, EpsteinBarr virus, hepatitis $\mathrm{A}$ and $\mathrm{C}$, and HIV. The manufacturing process must define the distinct biological characteristics of the cells, and their stability throughout the isolation, storage, and shipping process, and must provide quality assurance/control of the various components used. The manufacturing facility must meet rigorous standards with respect to its construction. The facility must monitor air handling, ambient temperature, humidity, water source and quality. The operating site itself must meet construction standards concerning flooring and wall materials, sealing between surfaces, traffic flow between designated clean and dirty rooms, and maintenance of positive air pressure gradients between such spaces. To insure that the facility meets these standards, the operators are required to monitor particle counts per cubic meter of air on a routine basis and to maintain records certifying the continuous operation of the equipment within designated environmental parameters. Likewise, the scientific equipment, instruments, and materials need to meet similar standards. The operation of all biological safety cabinets, incubators, water baths, and related equipment must be certified at least annually. All standard operating procedures must be documented. These documents must provide a detailed description of all routine laboratory methods as well as those activities required to support the manufacturing space, such as cleaning of biological safety cabinets and incubators, mopping of floors, walls and ceilings, and receipt and storage of perishable and nonperishable materials. By design, standard operating procedures should be written in a format that allows anyone knowledgeable in the field to conduct the procedures independently, with minimal oversight. Needless to say, the costs to meet the requirements for current good manufacturing practice certification are substantial. 
Table 2. Published clinical case reports and clinical trials

\begin{tabular}{|c|c|c|c|c|}
\hline Indication & Study type & Number of patients & Follow-up period & References \\
\hline \multicolumn{5}{|l|}{ Soft tissue } \\
\hline Breast augmentation & Case reports & 403 & Up to 6 years & $\begin{array}{c}\text { [9-1 1] (K Yoshimura, personal communication, } \\
\text { University of Tokyo) }\end{array}$ \\
\hline Craniofacial & Case reports & 58 & 9 to 13 months & $\begin{array}{c}{[10,21] \text { (K Yoshimura, personal communication, }} \\
\text { University of Tokyo) }\end{array}$ \\
\hline Irradiation fibrosis & Case reports & 20 & 31 months & [18] \\
\hline \multicolumn{5}{|l|}{ Orthopedic } \\
\hline Craniofacial & Case reports & 2 & $>12$ months & {$[25,26]$} \\
\hline \multicolumn{5}{|l|}{ Immune } \\
\hline Crohn's disease & Phase I & 5 to 9 & 12 to 30 months & {$[27-31]$} \\
\hline Multiple sclerosis & Case reports & 3 & 7 months & {$[33]$} \\
\hline
\end{tabular}

There is a demand to make minimally manipulated adipose-derived cell products directly available to the surgeon in the operating room. To meet this need, Cytori Therapeutics (San Diego, CA, USA) and Tissue Genesis (Honolulu, HI, USA) have designed and manufactured devices with a single, closed, disposable container that is used to harvest, to collagenase digest, to centrifuge, and to separate the lipoaspirate into mature adipocytes and SVF cells within a short time frame (1 hour or less) $[7,8]$. These SVF cells, which fulfill many if not all criteria for a minimally manipulated product, can then be reintroduced into the donor for cosmetic, reconstructive, or other purposes by the surgeon. Tissue-processing devices are now marketed in Europe and Asia, and are under regulatory review for distribution in the US. It will be important to monitor outcomes from procedures employing these devices in the next decade. Although these devices are designed to guarantee consistent and reproducible results, it remains to be determined whether the operator technique introduces any variability with respect to surgical procedures using SVF cells.

\section{Published clinical study reports}

\section{Soft tissue cosmetic and reconstructive surgery}

Soft tissue repair is a logical application - and, theoretically, the simplest application - for adipose-derived cell therapies since the isolated cells presumably do not need to display any transdifferentiation potential. Both ASCs and SVF cells have been approved and employed in clinical trials involving soft tissue defects (summarized along with other published clinical studies in Table 2). Breast reconstruction or augmentation trials have enrolled the greatest number of patients. Plastic surgeons at the University of Tokyo have reported pioneering results using SVF cells in combination with intact lipoaspirate tissues. Yoshimura and colleagues have combined SVF cells with lipoaspirates from equal volumes of tissue to augment breast volume [9-11]. In their clinical population of $>70$ subjects, these authors note improved fat grafting in the presence of the SVF cells with retention of volume for $>1$ year without evidence of fibrosis or adhesions. Complications such as cyst formation or microcalcifications occur in less than 2 to $3 \%$ of patients. Clinical trial reports in abstract form conducted by surgeons in Spain, South Korea, and elsewhere suggest similar outcomes [12].

It will be necessary to monitor patients for an extended period postoperatively. Some clinicians have raised concerns that morphological changes resulting from SVF cell/fat graft implants will complicate mammographic surveillance for breast cancer in recipients [13]. In addition, multiple studies have demonstrated that ASCs release growth factors/cytokines that attenuate the innate immune response [14-16]. Because of this immunosuppressive function, it is possible that the introduction of ASCs into breast tissue will create a microenvironment that favors or promotes the growth of rare tumor cells [17]. Long-term studies will therefore be required to compare the incidence of breast cancer in SVF cellimplanted and ASC-implanted patients with the incidence in untreated controls.

Breast cancer patients often undergo radiation treatment to the axilla post mastectomy, and this can be complicated by progressive fibrotic lesions of the exposed skin and dermis, resulting in an impaired range of motion in the upper extremity. In pilot clinical studies, surgeons have noted significant improvements following subcutaneous autologous fat transplants [18]. Recipients with chronic open lesions of the skin prior to treatment healed over time, characterized by enhanced microcapillary growth at the histological level. The irradiated skin at the transplantation sites became more supple, allowing the patients to recover an increased range of motion in their arm. These changes have been attributed to the presence of SVF cells and ASCs in the fat graft. It is likely that similar approaches may benefit subjects with chronic 
open wounds from other causes, such as decubit ulcers in bedridden patients and diabetic patients.

While plastic surgeons have used autologous fat grafts for over a century, there is substantial variability between surgeons with respect to the success of these procedures $[19,20]$. The fat grafts often lose volume, undergo fibrosis, or lead to necrosis. The University of Tokyo group used SVF cell/fat graft transplantation to treat craniofacial lipodystrophic and cosmetic defects with a high degree of success [21]. This suggests that the presence of the SVF cells, possibly due to their release of cytokines, improves the autologous fat graft viability and implantation. This hypothesis may reflect the ability of the SVF cells/ASCs to improve angiogenesis/ vascularity around the implant, to scavenge reactive oxygen species, and/or to enhance adipocyte progenitor survival, proliferation, and differentiation.

\section{Orthopedics}

The use of SVF cells and ASCs for bone repair has been a target for many investigators. There are close developmental links between adipose tissue and bone, and it has been postulated that an inverse or reciprocal relationship exists between adipogenesis and osteogenesis at the cellular level [22-24].

Investigators at the Universities of Tampere and Helsinki (Finland) published exciting clinical translational outcomes using autologous ASCs to repair a craniofacial defect [25]. The patient was a 68-year-old male who had lost part of the hard palate of the mouth following removal of a cyst. The resulting defect left the subject without the ability to chew or drink effectively. To address this defect, the surgical team harvested $200 \mathrm{~g}$ autologous subcutaneous adipose tissue, isolated and culture expanded the ASCs in autologous serum, and seeded them in the presence of bone morphogenetic protein 2 onto a $\beta$-tricalcium phosphate scaffold fashioned into the shape of the lesion/defect. The ASC/ scaffold construct was implanted into the patient's rectus abdominis muscle and followed for evidence of mineralization radiographically over an 8-month period. At that time, the construct was resected and transplanted to the maxillofacial defect, where its intact epigastric artery blood supply was re-anastomosed to the facial artery. Subsequently, the ASC/scaffold implant integrated into the bone site with the formation of a normal oral epithelium and achieved sufficient structural stability to allow for the implantation of prosthetic teeth. The patient recovered full oral function and remained complication free for at least 1 year.

This case represents the first peer-reviewed report of SVF cells or ASCs employed for the complete clinical repair of a craniofacial or orthopedic defect [25]. Since this case report, the surgical team has conducted similar surgeries on $>20$ subjects with $>90 \%$ positive outcomes. This initial approach has used ASCs for bone repair in a nonweight-bearing site. It will be necessary to develop techniques that reduce the number of invasive surgeries required for each procedure. In this context, a case report was published in 2004 describing the repair of a chronic calvarial defect in a single operation using autologous ASCs in combination with an autologous bone graft and fibrin glue; the reproducibility of this surgical approach needs to be validated [26]. Furthermore, it remains to be determined whether satisfactory outcomes can be achieved using ASCs or SVF cells in the repair of criticalsized defects in long bones.

\section{Immune disease}

Crohn's disease is an inflammatory bowel disorder characterized by bloody stools, diarrhea, weight loss, and autoimmune-related symptoms. A particularly troubling complication for many patients is the development of fistulas between the bowel and the genitourinary tract. The fistulas display a poor rate of healing and often recur. Clinicians at the Autonomous University of Madrid have explored both autologous SVF cell-based and autologous ASC-based therapies for fistula repair [27-32]. Their approach has been to inject $50 \%$ of their recovered cells $2 \mathrm{~mm}$ under the epithelium along the fistula track. The remaining cells are then combined with fibrin glue and used to fill in the fistula directly. In multiple publications reporting on phase I trials involving four or five patients each, the Madrid team was able to heal $75 \%$ of chronic fistulas using culture-expanded ASCs. In a single trial of four patients, however, they only achieved a $25 \%$ repair of fistulas with nonexpanded SVF cells. They postulated that this might be related to the difference between the reported immunogenic properties of ASCs and SVF cells. While ASCs display immunosuppressive features and low expression of immunoreactive surface antigens in vitro, SVF cells lack any immunosuppressive function and stimulate T-cell proliferation in parallel assays. In light of the autoimmune etiology of Crohn's disease, these immunomodulatory features could account for the relative success or failure of the two adipose-derived cell populations.

Multiple sclerosis is a progressive inflammatory disease affecting the myelinated cells of the central nervous system. Over time, this disease leads to degenerative changes and loss of cognitive, motor and sensory function; often, these changes occur in a waxing and waning manner. While the etiology of the disease remains in question, there is compelling evidence supporting a role for an autoimmune component. This has been supported by a preclinical model of the disease known as experimental autoimmune encephalitis, whereby a multiple sclerosis-like symptomatology is induced by injection of 
animals with myelin basic protein, proteolipid protein, or myelin oligodendrocyte glycoprotein [33]. Based on this autoimmune association, clinical investigators in Costa Rica have begun phase I safety trials treating multiple sclerosis patients with intravenous administration of autologous SVF cells [34]. In their initial report, the investigators provide case reports on three individuals who each received two intravenous infusions, each of 25 to 75 million SVF cells. All patients tolerated the treatment without complications, and some experienced an improvement in symptoms.

These preliminary trials need to be followed rigorously with appropriate controls to insure both safety and efficacy. It remains to be determined whether the immunomodulatory functional differences between SVF cells and ASCs have relevance. It is possible that ASCs, which show evidence of immunosuppressive function, may be capable of suppressing the inflammatory features of multiple sclerosis more effectively than SVF cells. Additional preclinical modeling may help to address this issue.

\section{Future directions and challenges}

Peripheral vascular disease provides a promising target for adipose-derived cell therapies. Pioneering preclinical studies simultaneously published independently by groups in Indianapolis, Toulouse, and Frankfurt - and later confirmed by others in Japan and Korea - have demonstrated the protective effects of both SVF cells and ASCs against acute vascular injuries [35-41]. Using rodent hind-limb ischemia models, these investigators unequivocally demonstrated that intravenous infusion or intramuscular injection of adipose-derived cells accelerated recovery of blood supply to the damaged tissues and prevented necrosis over a 1-week period. The investigators concluded that production of the angiogenic/ vasculogenic cytokines hepatocyte growth factor and vascular endothelial growth factor accounted, in part, for the mechanism underlying the ASC and/or SVF cell actions $[37,40]$. These preclinical studies suggest that ASCs and SVF cells could be used to treat claudication and chronic vascular insufficiency in the lower extremities, such as that seen in patients with diabetes and related small-vessel diseases. Consequently, doctors at academic medical centers have begun to submit protocols to their national regulatory authorities for translational clinical trials; however, to date, no phase I safety or efficacy results have been published.

\section{Acute diseases}

Since the adipose-derived cell secretome contains angiogenic and vasculogenic cytokines with regenerative and neurotrophic properties, there has been considerable interest in testing the impact of ASCs and SVF cells on acute disorders. Transient ischemic injury underlies the pathophysiology of myocardial infarction, stroke, renal ischemia, obstruction of the small intestine by intussusuception or volvulus, and related conditions associated with trauma to the brain, spinal cord, and extremities. Because these conditions develop rapidly, it follows that there is a narrow window of opportunity following the ischemic event to attenuate any pathological consequences. Theoretically, this window of time may close as reactive oxygen species are generated when postischemic reperfusion is established. In preclinical animal myocardial infarction models, ASC treatment shortly after the event improves ventricular function as compared with untreated controls or experimental groups where treatment was delayed [42,43]. In stroke models, ASC infusion during the immediate postischemic period accelerated recovery of motor function in rats [44-46]. Additional studies have explored the regenerative capacity of ASCs in models of spinal cord injury [47]. Nevertheless, while phase I trials using ASCs or SVF cells have been registered for each of these clinical diseases, outcome data have been limited to abstract presentations at national and international meetings.

\section{Chronic diseases}

Theoretically, acute diseases present situations where rapid intervention can most efficiently prevent the development of long-term pathologies. In contrast, chronic diseases may be less amenable to cell-based therapies. Preclinical animal models suggest that adult stem cells of bone marrow origin can be used to treat type 1 diabetes mellitus, chronic heart failure, and neurodegenerative diseases due to inborn errors of metabolism (Krabbe's disease, among others). Since these chronic diseases account for the majority of healthcare costs in most national economies, there is interest in using ASCs and SVF cells for their treatment.

There is particular interest in the use of ASCs and adipose transplantation therapy for lipodystrophy and associated metabolic disorders such as diabetes [48]. A single group in India has reported improved insulin sensitivity in group of five diabetic patients co-infused with ASCs and unfractionated cultured bone marrow cells [49]; however, the majority of studies have been limited to animal models. For example, our group has begun to explore the use of ASC therapy in murine and nonhuman primate models of Krabbe's disease (BA Bunnell and JM Gimble, unpublished data). After such small and large preclinical animal model data supporting the safety and efficacy of these approaches are reviewed, it will be possible to begin testing adipose-derived cells in these important human conditions. A positive outcome in a single disease alone could have substantial economic and public health benefits. 


\section{Conclusions: opportunities or roadblocks?}

The application of ASCs and SVF cells is still in its infancy and the field has made progressive advances towards clinical applications. In general, the clinical investigators who have published their findings have taken pains to address the important regulatory questions before advancing from animal models to patients. These researchers are to be applauded for treating the regulatory guidelines not as roadblocks but as opportunities for documenting the safety of their cell-based products. Still, there have not been many published safety studies addressing the legitimate concerns of regulatory authorities that include the following questions.

Can human ASCs and SVF cell implants cause tumors either directly through transformation or indirectly by promoting the growth of endogenous tumor cells? At least one manuscript has reported that human ASCs expanded long term in vitro will cause sarcomas when implanted in vivo in an immunodeficient mouse [50].

Has a current good manufacturing practice scheme of manufacture been developed for the cell products? While this information must be available to support existing clinical trials, details of standard operating protocols have not been made public. International standardization of ASCs and SVF cells would significantly advance clinical translation. Published definition of the cell identity with a panel of surface antigens and establishment of universally applied quality assurance/ quality control testing criteria would benefit the fledgling adipose stem cell community.

As discussed above, there is no shortage of diseases both acute and chronic - where adipose-derived cell therapies could have a potential clinical impact. The next steps will include documenting the reproducibility of the current preclinical and clinical findings, and controlled testing of the safety and efficacy of ASCs and SVF cells in a range of human conditions. In another decade, we postulate that the cells will prove beneficial to some, but not all, of the disease models tested. We expect initial successes to come in applications relating to acute disorders; however, we are hopeful that chronic diseases amenable to SVF cell therapy or ASC therapy will also be identified.

\section{Abbreviations}

ASC, adipose-derived stromal/stem cell; SVF, stromal vascular fraction.

\section{Competing interests}

JMG has consulted for and collaborated with a number of companies pursuing ASC-related technologies, including Cognate Bioservices, Toucan Capital, Vesta Therapeutics, Vet-Stem, and Zen-Bio. He has co-founded two companies exploring the tissue engineering and regenerative medical applications of ASCs: Artecel Sciences and LaCell, LLC. FG is the founder of Cytex Therapeutics, Inc. BAB has no competing interests to declare.

\section{Author contributions}

JMG prepared the outline and wrote the initial draft of the manuscript. $B A B$ and $F G$ edited and revised both the outline and the draft manuscript, providing additional references and insights.

\section{Acknowledgements}

The authors wish to acknowledge Ms Laura Dallam for excellent administrative and editorial assistance, Pedro Carvalho for critically reading the manuscript, Kotaro Yoshimura, MD, for reading the manuscript and sharing unpublished clinical data, and the following agencies for funding: Pennington Biomedical Research Foundation (to JMG), NIH grants AR50245 and AR48852, the Duke Translational Medicine Institute (RR024128) (to FG), Louisiana Gene Therapy Research Consortium and Tulane University (to BAB).

\section{Author details}

'Stem Cell Biology Laboratory, Pennington Biomedical Research Center, Louisiana State University System, 6400 Perkins Road, Baton Rouge, LA 70808, USA. ${ }^{2}$ Department of Orthopedics, Louisiana State University Health Science Center, 1542 Tulane Avenue, Box T6-7, New Orleans LA 70112, USA. ${ }^{3}$ Division of Orthopaedic Surgery, Department of Surgery, 375 Medical Sciences Research Building, DUMC Box 3093, Duke University Medical Center, Durham, NC 27710, USA. ${ }^{4}$ Tulane Center for Gene Therapy, Tulane University Health Sciences Center, J. Bennett Johnston Building, 1324 Tulane Avenue, SL-99, New Orleans, LA 70112-2699, USA. ${ }^{5}$ Tulane National Primate Research Center, 18703 Three Rivers Road, Covington, LA 70433-8915, USA.

Published: 29 June 2010

\section{References}

1. Gimble J, Guilak F: Adipose-derived adult stem cells: isolation, characterization, and differentiation potential. Cytotherapy 2003, 5:362-369.

2. Gimble JM, Katz AJ, Bunnell BA: Adipose-derived stem cells for regenerative medicine. Circ Res 2007, 100:1249-1260.

3. Gimble JM, Guilak F, Nutall ME, Sathishkumar S, Vidal MA, Bunnell BA: In vitro differentiation potential of mesenchymal stem cells. Transfus Med Hemother 2008, 35:228-238.

4. Locke M, Windsor J, Dunbar PR: Human adipose-derived stem cells: isolation, characterization and applications in surgery. ANZ J Surg 2009, 79:235-244.

5. Food and Drug Administration [http://www.fda.gov/ BiologicsBloodVaccines/GuidanceComplianceRegulatorylnformation/ default.htm]

6. European Medicines Agency [http://www.ema.europa.eu/pdfs/human/ cat/57113409en.pdf]

7. Lin K, Matsubara Y, Masuda Y, Togashi K, Ohno T, Tamura T, Toyoshima Y, Sugimachi K, Toyoda M, Marc H, Douglas A: Characterization of adipose tissue-derived cells isolated with the Celution system. Cytotherapy 2008, 10:417-426.

8. Zhu M, Zhou Z, Chen Y, Schreiber R, Ransom JT, Fraser JK, Hedrick MH, Pinkernell K, Kuo HC: Supplementation of fat grafts with adipose-derived regenerative cells improves long-term graft retention. Ann Plast Surg 2010, 64:222-228

9. Matsumoto D, Sato K, Gonda K, Takaki Y, Shigeura T, Sato T, Aiba-Kojima E, lizuka F, Inoue I, Suga H, Yoshimura K: Cell-assisted lipotransfer (CAL): supportive use of human adipose-derived cells for soft tissue augmentation with lipoinjection. Tissue Eng 2006, 12:3375-3382.

10. Yoshimura K, Sato K, Aoi N, Kurita M, Inoue K, Suga H, Eto H, Kato H, Hirohi T, Harii K: Cell-assisted lipotransfer for cosmetic breast augmentation: supportive use of adipose-derived stem/stromal cells. Aesthetic Plast Surg 2008, 32:48-55; discussion 56-57.

11. Yoshimura K, Asano Y, Aoi N, Kurita M, Oshima Y, Sato K, Inoue K, Suga H, Eto $\mathrm{H}$, Kato H, Harii K: Progenitor-enriched adipose tissue transplantation as rescue for breast implant complications. Breast J 2010, 16:169-175.

12. Kim MH, Kim I, Kim SH, Jung MK, Han S, Lee JE, Nam JS, Lee SK, Bang SI: Cryopreserved human adipogenic-differentiated pre-adipocytes: a potential new source for adipose tissue regeneration. Cytotherapy 2007, 9:468-476.

13. Mojallal A, Saint-Cyr M, Garrido I: Autologous fat transfer: controversies and current indications for breast surgery. J Plast Reconstr Aesthet Surg 2009, 62:708-710

14. Mclntosh K, Zvonic S, Garrett S, Mitchell JB, Floyd ZE, Hammill L, Kloster A, Di Halvorsen Y, Ting JP, Storms RW, Goh B, Kilroy G, Wu X, Gimble JM: The immunogenicity of human adipose derived cells: temporal changes in vitro. Stem Cells 2006, 24:1245-1253.

15. Cui L, Yin S, Liu W, Li N, Zhang W, Cao Y: Expanded adipose-derived stem cells suppress mixed lymphocyte reaction by secretion of prostaglandin E2. Tissue Eng 2007, 13:1185-1195. 
16. Puissant B, Barreau C, Bourin P, Clavel C, Corre J, Bousquet C, Taureau C, Cousin B, Abbal M, Laharrague P, Penicaud L, Casteilla L, Blancher A: Immunomodulatory effect of human adipose tissue-derived adult stem cells: comparison with bone marrow mesenchymal stem cells. $\mathrm{Br} J$ Haematol 2005, 129:118-129.

17. Xu F, Gomillion C, Maxson S, Burg KJ: In vitro interaction between mouse breast cancer cells and mouse mesenchymal stem cells during adipocyte differentiation. J Tissue Eng Regen Med 2009, 3:338-347.

18. Rigotti G, Marchi A, Galiè M, Baroni G, Benati D, Krampera M, Pasini A, Sbarbati $A$ : Clinical treatment of radiotherapy tissue damage by lipoaspirate transplant: a healing process mediated by adipose-derived adult stem cells. Plast Reconstr Surg 2007, 119:1409-1422; discussion 1423-1424.

19. Billings E, Jr, May JW, Jr: Historical review and present status of free fat graft autotransplantation in plastic and reconstructive surgery. Plast Reconstr Surg 1989, 83:368-381.

20. Ellenbogen R: Free autogenous pearl fat grafts in the face - a preliminary report of a rediscovered technique. Ann Plast Surg 1986, 16:179-194.

21. Yoshimura K, Sato K, Aoi N, Kurita M, Inoue K, Suga H, Eto H, Kato H, Hirohi T, Harii K: Cell-assisted lipotransfer for facial lipoatrophy: efficacy of clinical use of adipose-derived stem cells. Dermato/ Surg 2008, 34:1178-1185.

22. Gimble JM: The function of adipocytes in the bone marrow stroma. New Biol 1990, 2:304-312.

23. Gimble JM, Robinson CE, Wu X, Kelly KA: The function of adipocytes in the bone marrow stroma: an update. Bone 1996, 19:421-428.

24. Gimble JM, Zvonic S, Floyd ZE, Kassem M, Nuttall ME: Playing with bone and fat. J Cell Biochem 2006, 98:251-266.

25. Mesimäki K, Lindroos B, Törnwall J, Mauno J, Lindqvist C, Kontio R, Miettinen S, Suuronen R: Novel maxillary reconstruction with ectopic bone formation by GMP adipose stem cells. Int J Oral Maxillofac Surg 2009, 38:201-209.

26. Lendeckel S, Jödicke A, Christophis P, Heidinger K, Wolff J, Fraser JK, Hedrick $\mathrm{MH}$, Berthold L, Howaldt HP: Autologous stem cells (adipose) and fibrin glue used to treat widespread traumatic calvarial defects: case report. J Craniomaxillofac Surg 2004, 32:370-373.

27. García-Olmo D, García-Arranz M, García LG, Cuellar ES, Blanco IF, Prianes LA, Montes JA, Pinto FL, Marcos DH, García-Sancho L: Autologous stem cell transplantation for treatment of rectovaginal fistula in perianal Crohn's disease: a new cell-based therapy. Int J Colorectal Dis 2003, 18:451-454.

28. Garcia-Olmo D, Garcia-Arranz M, Herreros D: Expanded adipose-derived stem cells for the treatment of complex perianal fistula including Crohn's disease. Expert Opin Biol Ther 2008, 8:1417-1423.

29. García-Olmo D, García-Arranz M, Herreros D, Pascual I, Peiro C, RodríguezMontes JA: A phase I clinical trial of the treatment of Crohn's fistula by adipose mesenchymal stem cell transplantation. Dis Colon Rectum 2005, 48:1416-1423

30. Garcia-Olmo D, Herreros D, Pascual I, Pascual JA, Del-Valle E, Zorrilla J, De-LaQuintana P, Garcia-Arranz M, Pascual M: Expanded adipose-derived stem cells for the treatment of complex perianal fistula: a phase II clinical trial. Dis Colon Rectum 2009, 52:79-86.

31. Garcia-Olmo D, Herreros D, Pascual M, Pascual I, De-La-Quintana P, Trebol J, Garcia-Arranz M: Treatment of enterocutaneous fistula in Crohn's disease with adipose-derived stem cells: a comparison of protocols with and without cell expansion. Int J Colorectal Dis 2009, 24:27-30.

32. Taxonera C, Schwartz DA, Garcia-Olmo D: Emerging treatments for complex perianal fistula in Crohn's disease. World J Gastroenterol 2009, 15:4263-4272.

33. Constantin G, Marconi S, Rossi B, Angiari S, Calderan L, Anghileri E, Gini B, Bach SD, Martinello M, Bifari F, Galiè M, Turano E, Budui S, Sbarbati A, Krampera M, Bonetti B: Adipose-derived mesenchymal stem cells ameliorate chronic experimental autoimmune encephalomyelitis. Stem Cells 2009, 27:2624-2635.

34. Riordan NH, Ichim TE, Min WP, Wang H, Solano F, Lara F, Alfaro M, Rodriguez JP, Harman RJ, Patel AN, Murphy MP, Lee RR, Minev B: Non-expanded adipose stromal vascular fraction cell therapy for multiple sclerosis. J Trans/Med 2009, 7:29.

35. Miranville $A$, Heeschen $C$, Sengenès $C$, Curat $C A$, Busse $R$, Bouloumié $A$ : Improvement of postnatal neovascularization by human adipose tissuederived stem cells. Circulation 2004, 110:349-355.

36. Planat-Benard V, Silvestre JS, Cousin B, André M, Nibbelink M, Tamarat R, Clergue M, Manneville C, Saillan-Barreau C, Duriez M, Tedgui A, Levy B, Pénicaud L, Casteilla L: Plasticity of human adipose lineage cells toward endothelial cells: physiological and therapeutic perspectives. Circulation 2004, 109:656-663.
37. Rehman J, Traktuev D, Li J, Merfeld-Clauss S, Temm-Grove CJ, Bovenkerk JE, Pell CL, Johnstone BH, Considine RV, March KL: Secretion of angiogenic and antiapoptotic factors by human adipose stromal cells. Circulation 2004, 109:1292-1298.

38. Nakagami H, Maeda K, Morishita R, Iguchi S, Nishikawa T, Takami Y, Kikuchi Y, Saito Y, Tamai K, Ogihara T, Kaneda Y: Novel autologous cell therapy in ischemic limb disease through growth factor secretion by cultured adipose tissue-derived stromal cells. Arterioscler Thromb Vasc Biol 2005, 25:2542-2547.

39. Nakagami H, Morishita R, Maeda K, Kikuchi Y, Ogihara T, Kaneda Y: Adipose tissue-derived stromal cells as a novel option for regenerative cell therapy. J Atheroscler Thromb 2006, 13:77-81.

40. Bhang SH, Cho SW, Lim JM, Kang JM, Lee TJ, Yang HS, Song YS, Park MH, Kim HS, Yoo KJ, Jang Y, Langer R, Anderson DG, Kim BS: Locally delivered growth factor enhances the angiogenic efficacy of adipose-derived stromal cells transplanted to ischemic limbs. Stem Cells 2009, 27:1976-1986.

41. Moon MH, Kim SY, Kim YJ, Kim SJ, Lee JB, Bae YC, Sung SM, Jung JS: Human adipose tissue-derived mesenchymal stem cells improve postnatal neovascularization in a mouse model of hindlimb ischemia. Cell Physiol Biochem 2006, 17:279-290.

42. Cai L, Johnstone BH, Cook TG, Tan J, Fishbein MC, Chen PS, March KL: IFATS collection: human adipose tissue-derived stem cells induce angiogenesis and nerve sprouting following myocardial infarction, in conjunction with potent preservation of cardiac function. Stem Cells 2009, 27:230-237.

43. Bai X, Yan Y, Song YH, Seidensticker M, Rabinovich B, Metzele R, Bankson JA, Vykoukal D, Alt E: Both cultured and freshly isolated adipose tissue-derived stem cells enhance cardiac function after acute myocardial infarction. Eur Heart J 31:489-501.

44. Kim JM, Lee ST, Chu K, Jung KH, Song EC, Kim SJ, Sinn DI, Kim JH, Park DK, Kang KM, Hyung Hong N, Park HK, Won CH, Kim KH, Kim M, Kun Lee S, Roh JK: Systemic transplantation of human adipose stem cells attenuated cerebral inflammation and degeneration in a hemorrhagic stroke model. Brain Res 2007, 1183:43-50.

45. Kim Y, Kim H, Cho H, Bae Y, Suh K, Jung J: Direct comparison of human mesenchymal stem cells derived from adipose tissues and bone marrow in mediating neovascularization in response to vascular ischemia. Cell Physiol Biochem 2007, 20:867-876.

46. Kang SK, Lee DH, Bae YC, Kim HK, Baik SY, Jung JS: Improvement of neurological deficits by intracerebral transplantation of human adipose tissue-derived stromal cells after cerebral ischemia in rats. Exp Neuro/ 2003, 183:355-366.

47. Kang SK, Shin MJ, Jung JS, Kim YG, Kim CH: Autologous adipose tissuederived stromal cells for treatment of spinal cord injury. Stem Cells Dev 2006, 15:583-594.

48. Tran TT, Kahn CR: Transplantation of adipose tissue and stem cells: role in metabolism and disease. Nat Rev Endocrinol 6:195-213.

49. Trivedi HL, Vanikar AV, Thakker U, Firoze A, Dave SD, Patel CN, Patel JV, Bhargava AB, Shankar V: Human adipose tissue-derived mesenchymal stem cells combined with hematopoietic stem cell transplantation synthesize insulin. Transplant Proc 2008, 40:1135-1139.

50. Rubio D, Garcia-Castro J, Martín MC, de la Fuente R, Cigudosa JC, Lloyd AC, Bernad A: Spontaneous human adult stem cell transformation. Cancer Res 2005, 65:3035-3039.

51. Halberstadt C, Austin C, Rowley J, Culberson C, Loebsack A, Wyatt S, Coleman S, Blacksten L, Burg K, Mooney D, Holder W Jr: A hydrogel material for plastic and reconstructive applications injected into the subcutaneous space of a sheep. Tissue Eng 2002, 8:309-319.

52. Patrick CW Jr, Chauvin PB, Hobley J, Reece GP: Preadipocyte seeded PLGA scaffolds for adipose tissue engineering. Tissue Eng 1999, 5:139-151.

53. Patrick CW, Jr, Wu X: Integrin-mediated preadipocyte adhesion and migration on laminin-1. Ann Biomed Eng 2003, 31:505-514.

54. Patrick CW Jr, Zheng B, Johnston C, Reece GP: Long-term implantation of preadipocyte-seeded PLGA scaffolds. Tissue Eng 2002, 8:283-293.

55. Kawaguchi N, Toriyama K, Nicodemou-Lena E, Inou K, Torii S, Kitagawa Y: De novo adipogenesis in mice at the site of injection of basement membrane and basic fibroblast growth factor. Proc Natl Acad Sci U S A 1998, 95:1062-1066

56. Mauney JR, Nguyen T, Gillen K, Kirker-Head C, Gimble JM, Kaplan DL: Engineering adipose-like tissue in vitro and in vivo utilizing human bone marrow and adipose-derived mesenchymal stem cells with silk fibroin 3D scaffolds. Biomaterials 2007, 28:5280-5290. 
57. Tabata Y, Miyao M, Inamoto T, Ishii T, Hirano Y, Yamaoki Y, Ikada Y: De novo formation of adipose tissue by controlled release of basic fibroblast growth factor. Tissue Eng 2000, 6:279-289.

58. Toriyama K, Kawaguchi N, Kitoh J, Tajima R, Inou K, Kitagawa Y, Torii S: Endogenous adipocyte precursor cells for regenerative soft-tissue engineering. Tissue Eng 2002, 8:157-165.

59. Kimura Y, Ozeki M, Inamoto T, Tabata Y: Time course of de novo adipogenesis in matrigel by gelatin microspheres incorporating basic fibroblast growth factor. Tissue Eng 2002, 8:603-613.

60. Kimura Y, Ozeki M, Inamoto T, Tabata Y: Adipose tissue engineering based on human preadipocytes combined with gelatin microspheres containing basic fibroblast growth factor. Biomaterials 2003, 24:2513-2521.

61. Rodeheffer MS, Birsoy K, Friedman JM: Identification of white adipocyte progenitor cells in vivo. Cell 2008, 135:240-249.

62. Ebrahimian TG, Pouzoulet F, Squiban C, Buard V, André M, Cousin B, Gourmelon P, Benderitter M, Casteilla L, Tamarat R: Cell therapy based on adipose tissue-derived stromal cells promotes physiological and pathological wound healing. Arterioscler Thromb Vasc Bio/ 2009, 29:503-510.

63. Poglio S, Galvani S, Bour S, André M, Prunet-Marcassus B, Pénicaud L, Casteilla $L$, Cousin B: Adipose tissue sensitivity to radiation exposure. Am J Pathol 2009, 174:44-53

64. Altman AM, Yan Y, Matthias N, Bai X, Rios C, Mathur AB, Song YH, Alt EU: IFATS collection: human adipose-derived stem cells seeded on a silk fibroinchitosan scaffold enhance wound repair in a murine soft tissue injury model. Stem Cells 2009, 27:250-258.

65. Cowan CM, Aalami OO, Shi YY, Chou YF, Mari C, Thomas R, Quarto N, Nacamuli $\mathrm{RP}$, Contag $\mathrm{CH}, \mathrm{Wu} \mathrm{B}$, Longaker MT: Bone morphogenetic protein 2 and retinoic acid accelerate in vivo bone formation, osteoclast recruitment, and bone turnover. Tissue Eng 2005, 11:645-658.

66. Cowan CM, Shi YY, Aalami OO, Chou YF, Mari C, Thomas R, Quarto N, Contag $\mathrm{CH}$, Wu B, Longaker MT: Adipose-derived adult stromal cells heal criticalsize mouse calvarial defects. Nat Biotechnol 2004, 22:560-567.

67. Dragoo JL, Choi JY, Lieberman JR, Huang J, Zuk PA, Zhang J, Hedrick MH, Benhaim P: Bone induction by BMP-2 transduced stem cells derived from human fat. J Orthop Res 2003, 21:622-629.

68. Lopez MJ, Mclntosh KR, Spencer ND, Borneman JN, Horswell R, Anderson P, Yu G, Gaschen L, Gimble JM: Acceleration of spinal fusion using syngeneic and allogeneic adult adipose derived stem cells in a rat model. $J$ Orthop Res 2009, 27:366-373

69. Mclntosh KR, Lopez MJ, Borneman JN, Spencer ND, Anderson PA, Gimble JM: Immunogenicity of allogeneic adipose-derived stem cells in a rat spinal fusion model. Tissue Eng Part A 2009, 15:2677-2686.

70. Miyahara Y, Nagaya N, Kataoka M, Yanagawa B, Tanaka K, Hao H, Ishino K, Ishida H, Shimizu T, Kangawa K, Sano S, Okano T, Kitamura S, Mori H: Monolayered mesenchymal stem cells repair scarred myocardium after myocardial infarction. Nat Med 2006, 12:459-465.

71. Choi YS, Matsuda K, Dusting GJ, Morrison WA, Dilley RJ: Engineering cardiac tissue in vivo from human adipose-derived stem cells. Biomaterials 31:2236-2242

72. Kubis N, Tomita Y, Tran-Dinh A, Planat-Benard V, André M, Karaszewski B, Waeckel L, Pénicaud L, Silvestre JS, Casteilla L, Seylaz J, Pinard E: Vascular fate of adipose tissue-derived adult stromal cells in the ischemic murine brain: a combined imaging-histological study. Neuroimage 2007, 34:1-11.

73. González MA, Gonzalez-Rey E, Rico L, Büscher D, Delgado M: Adiposederived mesenchymal stem cells alleviate experimental colitis by inhibiting inflammatory and autoimmune responses. Gastroenterology 2009, 136:978-989.

74. Kim SJ, Cho HH, Kim YJ, Seo SY, Kim HN, Lee JB, Kim JH, Chung JS, Jung JS: Human adipose stromal cells expanded in human serum promote engraftment of human peripheral blood hematopoietic stem cells in NOD/SCID mice. Biochem Biophys Res Commun 2005, 329:25-31.

75. Cousin B, André M, Arnaud E, Pénicaud L, Casteilla L: Reconstitution of lethally irradiated mice by cells isolated from adipose tissue. Biochem Biophys Res Commun 2003, 301:1016-1022.

76. Murphy JM, Fink DJ, Hunziker EB, Barry FP: Stem cell therapy in a caprine model of osteoarthritis. Arthritis Rheum 2003, 48:3464-3474.
77. Black LL, Gaynor J, Gahring D, Adams C, Aron D, Harman S, Gingerich DA Harman R: Effect of adipose-derived mesenchymal stem and regenerative cells on lameness in dogs with chronic osteoarthritis of the coxofemoral joints: a randomized, double-blinded, multicenter, controlled trial. Vet Ther 2007, 8:272-284

78. Black LL, Gaynor J, Adams C, Dhupa S, Sams AE, Taylor R, Harman S, Gingerich DA, Harman R: Effect of intraarticular injection of autologous adiposederived mesenchymal stem and regenerative cells on clinical signs of chronic osteoarthritis of the elbow joint in dogs. Vet Ther 2008, 9:192-200.

79. Frisbie DD, Kisiday JD, Kawcak CE, Werpy NM, Mcllwraith CW: Evaluation of adipose-derived stromal vascular fraction or bone marrow-derived mesenchymal stem cells for treatment of osteoarthritis. J Orthop Res 2009, 27:1675-1680.

80. Banas A, Teratani T, Yamamoto Y, Tokuhara M, Takeshita F, Quinn G, Okochi H, Ochiya T: Adipose tissue-derived mesenchymal stem cells as a source of human hepatocytes. Hepatology 2007, 46:219-228.

81. Ishikawa T, Banas A, Hagiwara K, Iwaguro H, Ochiya T: Stem cells for hepatic regeneration: the role of adipose tissue derived mesenchymal stem cells. Curr Stem Cell Res Ther 2010, 5:182-189.

82. Ochiya T, Yamamoto Y, Banas A: Commitment of stem cells into functional hepatocytes. Differentiation 2010, 79:65-73.

83. Banas A, Teratani T, Yamamoto Y, Tokuhara M, Takeshita F, Osaki M, Kato T, Okochi H, Ochiya T: Rapid hepatic fate specification of adipose-derived stem cells and their therapeutic potential for liver failure. $J$ Gastroenterol Hepatol 2009, 24:70-77

84. Banas A, Teratani T, Yamamoto Y, Tokuhara M, Takeshita F, Osaki M, Kawamata M, Kato T, Okochi H, Ochiya T: IFATS collection: in vivo therapeutic potential of human adipose tissue mesenchymal stem cells after transplantation into mice with liver injury. Stem Cells 2008, 26:2705-2712.

85. Seo MJ, Suh SY, Bae YC, Jung JS: Differentiation of human adipose stromal cells into hepatic lineage in vitro and in vivo. Biochem Biophys Res Commun 2005, 328:258-264

86. Aurich H, Sgodda M, Kaltwasser P, Vetter M, Weise A, Liehr T, Brulport M, Hengstler JG, Dollinger MM, Fleig WE, Christ B: Hepatocyte differentiation of mesenchymal stem cells from human adipose tissue in vitro promotes hepatic integration in vivo. Gut 2009, 58:570-581.

87. Taléns-Visconti R, Bonora A, Jover R, Mirabet V, Carbonell F, Castell JV, GómezLechón MJ: Hepatogenic differentiation of human mesenchymal stem cells from adipose tissue in comparison with bone marrow mesenchymal stem cells. World J Gastroentero/ 2006, 12:5834-5845.

88. Ruiz JC, Ludlow JW, Sherwood S, Yu G, Wu X, Gimble JM: Differentiated human adipose-derived stem cells exhibit hepatogenic capability in vitro and in vivo. $J$ Cell Physiol in press [Epub ahead of print]

89. Kajiyama H, Hamazaki TS, Tokuhara M, Masui S, Okabayashi K, Ohnuma K Yabe S, Yasuda K, Ishiura S, Okochi H, Asashima M: Pdx1-transfected adipose tissue-derived stem cells differentiate into insulin-producing cells in vivo and reduce hyperglycemia in diabetic mice. Int J Dev Biol 2010, 54:699-705.

90. Chandra V, Swetha G, Phadris S, Nair PD, Bhonde RR: Generation of pancreatic hormone-expressing islet-like cell aggregates from murine adipose tissue-derived stem cells. Stem Cells 2009, 27:1941-1953.

91. Blanton MW, Hadad I, Johnstone BH, Mund JA, Rogers PI, Eppley BL, March $\mathrm{KL}$ : Adipose stromal cells and platelet-rich plasma therapies synergistically increase revascularization during wound healing. Plast Reconstr Surg 2009, 123:56S-64S.

92. Nixon AJ, Dahlgren LA, Haupt UL, Yeager AE, Ward DL: Effect of adiposederived nucleated cell fractions on tendon repair in horses with collagenase-induced tendinitis. Am J Vet Res 2008, 69:928-937.

93. Jack GS, Almeida FG, Zhang R, Alfonso ZC, Zuk PA, Rodríguez LV: Processed lipoaspirate cells for tissue engineering of the lower urinary tract: implications for the treatment of stress urinary incontinence and bladder reconstruction. J Urol 2005, 174:2041-2045.

\section{doi:10.1186/scrt19}

Cite this article as: Gimble JM, et al.: Clinical and preclinical translation of cell-based therapies using adipose tissue-derived cells. Stem Cell Research \& Therapy 2010, 1:19. 